\title{
Performance Analysis of Plate Punching and Bending Machine Combination
}

\author{
Fazri Zaini Ibrahim, ${ }^{\mathrm{a},{ }^{*}}$ and Yohanes, \\ a) Laboratory Technology Production Mechanical Engineering Department, Universitas Riau, Indonesia \\ ${ }^{b)}$ Mechanical Engineering, Universitas Riau, Indonesia \\ *Corresponding author: yohanes@lecturer.unri.ac.id
}

\section{Paper History}

Received: 30-August-2021

Received in revised form: 25-October-2021

Accepted: 30-November-2021

\begin{abstract}
The plate punching and bending combination machine is a machine that belongs to the press type with the use of a punch and a die to make holes or bends in a plate work-piece. This machine uses a hydraulic drive with a maximum working pressure of 700 Bars, which is used as a punch force to workpiece. But, it is not known the value of working pressure this frame can withstand. Therefore, machine performance becomes unknown such as punch force that can be used, work-piece thickness, whole circumference and type of material that can be machined. In this paper, the analysis is carried out using simulation and experimental methods. The simulation method is carried out using Autodesk Inventor software to determine the critical location, which is then measured by experiment. The experimental method is carried out by measuring the stress and deflection. Voltage measurement on the frame is carried out using a strain gauge sensor and measurements are carried out using a dial indicator. The application of a safety factor is 1.5 based on the yield strength of ASTM A36 as the frame material. The deflection that has occurred is $1.15 \mathrm{~mm}$, the maximum working pressure obtained is 27.7 Bars. The maximum punch force is $5441 \mathrm{~N}$.
\end{abstract}

KEY WORDS: Working pressure, Punch force, Yield strength, Safety factor.

\section{NOMENCLATURE}

$\begin{array}{ll}\sigma_{y} & \text { Yield strength } \\ \sigma_{t} & \text { Tensile strength } \\ \sigma_{b} & \text { Stress limit } \\ Y & \text { Modulus Young } \\ S F & \text { Safety factor }\end{array}$

$\begin{array}{ll}A & \text { Actuator cross-sectional area } \\ t & \text { Work-piece thickness } \\ L & \text { Circumference of the punch } \\ F_{p} & \text { Punch force } \\ F_{p, \text { maks }} & \text { Maximum punch force } \\ p_{g} & \text { Pressure gauge } \\ F_{p, s} & \text { Simulation punch force } \\ p_{g, s} & \text { Simulation pressure gauge } \\ \sigma_{s} & \text { Simulation maximum stress } \\ \delta_{s} & \text { Simulation maximum deflection } \\ F_{p, e} & \text { Experiment punch force } \\ p_{g, e} & \text { Experiment pressure gauge } \\ \sigma_{e} & \text { Experiment maximum stress } \\ \delta_{e} & \text { Experiment maximum deflection } \\ \varepsilon & \text { Strain } \\ E_{i} & \text { Input voltage } \\ E_{o} & \text { Output voltage } \\ G F & \text { Factor gauge } \\ \Delta E_{o} & \text { Output voltage difference } \\ \Delta E_{o, g a i n} & \text { Amplified output voltage difference } \\ \Delta D A_{b} & \text { Analog data difference limit } \\ \Delta D A & \text { Analog data difference } \\ G & \text { Gain }\end{array}$

\subsection{INTRODUCTION}

Sheet metalworking processes include sheet metal cutting and sheet metal forming. To produce sheet metal products, cutting and forming operations are used. There are several types of operations, namely blanking, punching, bending, slitting, spinning, notching and others. Cutting operations in sheet metal production, especially blanking and punching, cannot be separated from the shear force generated by pressing the workpiece between the punch and the die to separate the part to be removed during cutting, which is called slug or scrap [1].

Rizza (in Budiarto, 1997) [2] states that the press tool is an equipment used for cutting and forming sheet metal into desired production goods with the help of emphasis. Based on this statement, the press tool can implement sheet metal work processes such as blanking, punching and bending using punch and die. 
To carry out these processes, plate punching and bending combination machine has been made. This machine was designed by Jhonny Harianto and Novri Yunus, students of the Diploma (D3) Mechanical Engineering Study Program in 2015, which was assembled in the production process technology laboratory, mechanical engineering, University of Riau [3]. This tool is designed to have a dual function, namely the blanking and punching process and the bending process, where these two processes can be distinguished from the type of punch and die tool used. In the first research in 2015 by Harianto and Yunus, when given a load, deflection occurs in the machine frame [3]. Then, research on this machine was continued in 2018 by Fahri Asrizal Lubis and Yohanes with the purpose of analyzing the effect of the tool punch shape on the cutting force and quality in the blanking process and varying burr height [4].

Stress is a form of reaction on the inside of a cross-section of an object caused by external force acting. The actual stress check can be done using the measurement method. The most frequently used stress measurement is the measurement using a strain gauge. Strain gauge is a sensor that can measure strain by attaching a strain gauge to an object under strain and then calculating the stress. The advantage of using a strain gauge in measuring stress is that it is able to measure stress at certain points due to the small dimensions of the strain gauge [5-6].

Deformation is a change in the shape of an object due to a load or force [7]. Deformation is divided into two types, namely plastic deformation and elastic deformation. Plastic deformation is a permanent change in the shape of an object, even when the object or force is removed. Elastic deformation is a change in the shape of an object due to a force, and when the force is removed, it returns to its original shape. Therefore Elastic deformation is used as a deformation in the design process because the maximum stress is limited below the yield point [8].

The punching and bending combination machine uses a hydraulic drive that can provide a working pressure of up to 700 bar [1]. When this machine performs the cutting process with a certain working pressure, stress occurs in the machine frame. So that the machine frame does not undergo plastic deformation, the applied working pressure must not cause the maximum stress that occurs in the machine frame to be greater than the yield stress. The maximum working pressure allowable was not undefined due to the performance of machine to be unknown, such as the thickness of the work piece, the diameter of the hole, the type of material that can be machined and the punch force required to punch the work piece.

From the research that has been done, the performance of the machine is unknown because the maximum allowable working pressure is not known. Therefore, in this paper proposed is to analysis the performance of plate punching and bending combination machine. This research is expected to determine the working pressure limit of the machine, the dimensions of the work piece, the type of material and the punch force required in the blanking and punching processes.

\subsection{METHOD}

The combination punch and plate bending machine is a machine that belongs to the type of press tool machine, the press tool works using a punch (moving part) and a die (a stationary part), the punch is driven by an actuator that moves translational using a hydraulic system. Technically the actuator moves the punch to press the work piece material that is placed on the die. The components of the punching and bending machine can be seen in Figure 1.

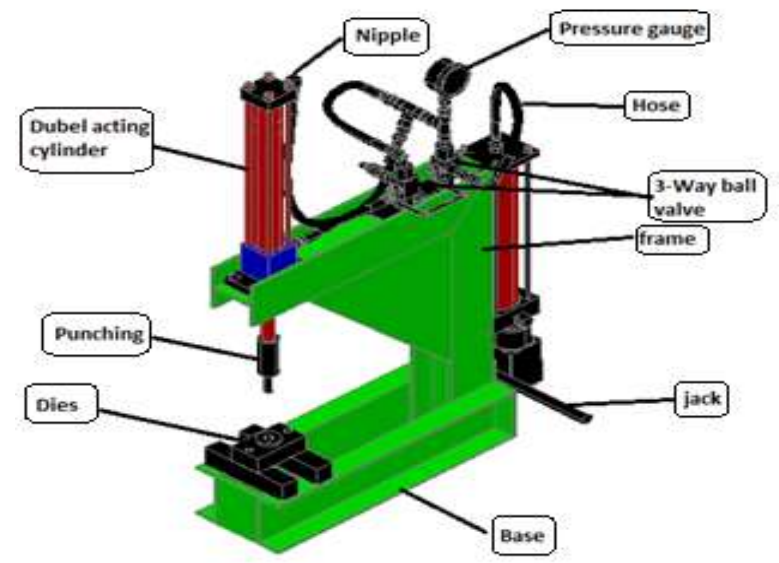

Figure 1: Punching and bending combination machine parts [1]

\subsection{Research Method}

In this research, several stages were carried out, while the flow of research activities is shown in Figure 2.

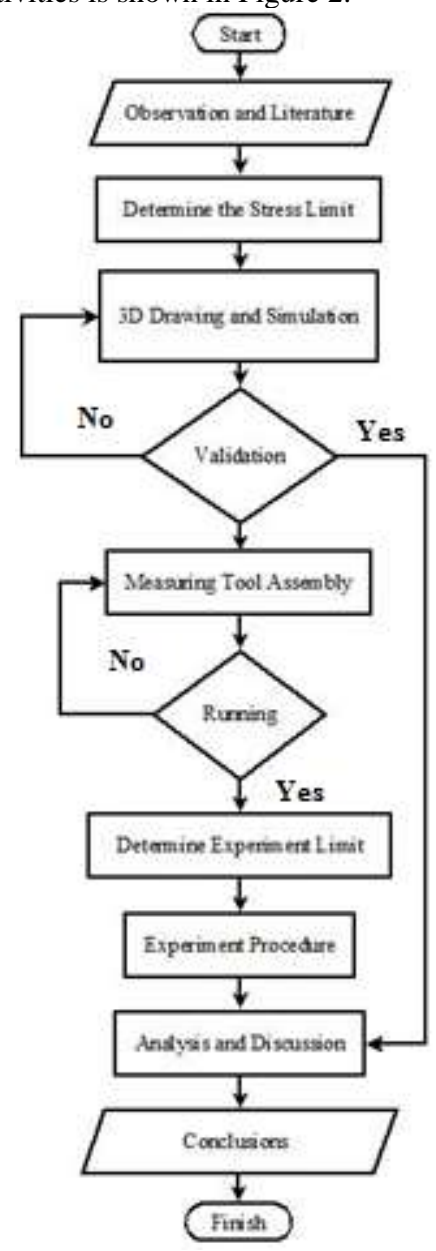

Figure 2: Research flow chart 


\subsection{Determining the Stress Limit}

The most suitable strength or stiffness criterion for a structural element or component is that generally some maximum stress or deformation should not be exceeded. In this case the rated stress is generally known as the maximum allowable working stress [9]. The maximum stress limit for this combination punching and bending machine is determined by a safety factor of 1.5 based on consideration of the yield stress. This machine uses ASTM A36 material as the frame with $\sigma_{y} 250 \mathrm{MPa}$.

$$
\begin{aligned}
S F & =\frac{\sigma_{y}}{\sigma_{b}} \\
\sigma_{b} & =\frac{\sigma_{y}}{S F} \\
\sigma_{b} & =\frac{250 \mathrm{MPa}}{1.5} \\
\sigma_{b} & =167 \mathrm{MPa}
\end{aligned}
$$

The working pressure applied to the machine should cause the maximum stress to be less than $167 \mathrm{MPa}$ so that the safety factor is not less than 1.5.

\subsection{D Drawing and Simulation}

This stage intends to determine the magnitude and location of the maximum stress (critical location) that occurs in the frame construction when it is given a load. The loading simulation uses the stress analysis simulation feature and the load is given to the load limit where the maximum stress that occurs in the frame does not exceed the yield strength. From the simulation obtained the maximum stress and its location. The maximum deflection and its location and the safety factor of the machine frame structure that is applied when the load is given.

Making a 3D drawing of the machine frame is done by measuring the dimensions of the machine frame first, and then the measurement result is modeled with Autodesk Inventor software. The 3D drawing is shown in Figure 3.

Before doing the simulation, there are inputs variables used and will affect the output of the simulation. The input variables used are shown in Table 1. The placement of the constraint is shown in Figure 4 and the placement of the loads is shown in Figure 5. In Figure 5, the yellow arrow indicates the load due to the punch force, the white arrow indicates the load due to the actuator gravity, the red arrow indicates the load due to the valve gravity and the green arrow indicates the load due to the

\begin{tabular}{|c|c|c|}
\hline \multicolumn{2}{|c|}{ Variable } & Information \\
\hline Material & & ASTM A36 \\
\hline$=$ & Young's Modulus $(Y)$ & $200 \mathrm{GPa}$ \\
\hline - & Shear Modulus & $78 \mathrm{GPa}$ \\
\hline- & Yield Strength $\left(\sigma_{y}\right)$ & - $\quad 250 \mathrm{MPa}$ \\
\hline - & Tensile Strength & - $\quad 400 \mathrm{MPa}$ \\
\hline Load & & Force \\
\hline- & Punch Force $\left(F_{p}\right)$ & $5100 \mathrm{~N}$ \\
\hline - & Achuator & $=\quad 104 \mathrm{~N}$ \\
\hline$=$ & Valve & $21.5 \mathrm{~N}$ \\
\hline . & Hydraulic Pump & $95 \mathrm{~N}$ \\
\hline $\begin{array}{l}\text { Safety F } \\
\text { Constrai }\end{array}$ & ictor & $\begin{array}{l}\text { Based on Yield Strength } \\
\text { Fixed }\end{array}$ \\
\hline
\end{tabular}
hydraulic pump gravity.

Table 1: Input Variables

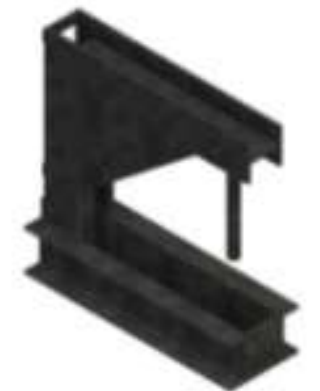

Figure 3: The 3D drawing of machine frame structure

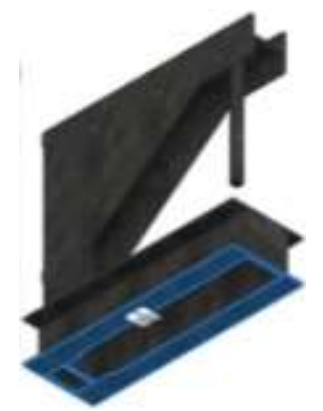

Figure 4: Constraint placement

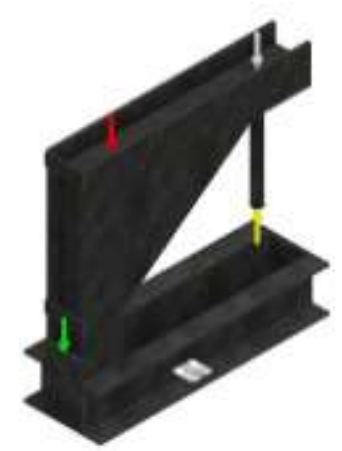

Figure 5: Load placement

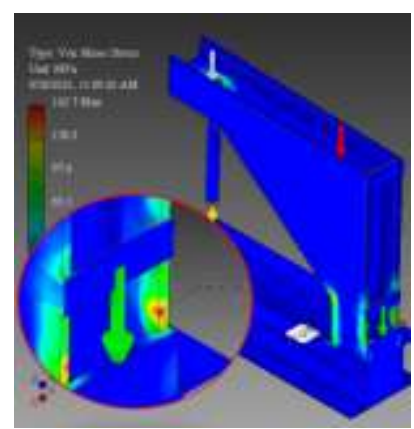

(a)

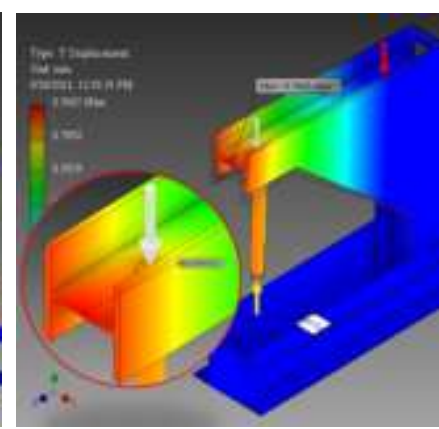

(b)
Figure 6: Location of maximum stress and deflection, (a) stress and (b) deflection

In Figure 6, the results were obtained after performing the simulation of the critical location with a stress of $162.7 \mathrm{MPa}$ $\left(\sigma_{\mathrm{s}}\right)$ and the location of the deflection with $0.9865 \mathrm{~mm}\left(\delta_{\mathrm{s}}\right)$. 


\subsection{Experimental Limit}

Figure 7 shows the data processing flow. The experimental limit that needs to be calculated first because the pressure applied to the machine must not cause the maximum stress that occurs to exceed the limit of $167 \mathrm{MPa}$.

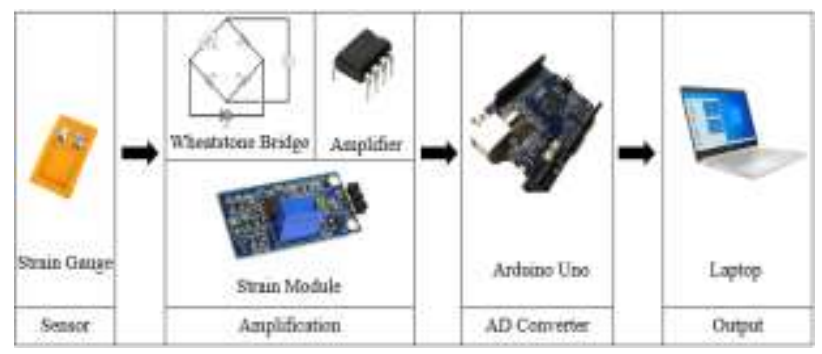

Figure 7: Data processing flow

a. Strain Limit

If the stress that occurs on an object is getting bigger, it will cause the strain of the object to be even greater. This relationship is in accordance with Hooke's law and expressed in Young's modulus [10]. So, the simulation and experimental results can be compared. The voltage is used a simulation of 162.7 MPa.

$$
\begin{aligned}
Y & =\frac{\sigma_{s}}{\varepsilon} \\
\varepsilon & =\frac{\sigma_{s}}{Y} \\
\varepsilon & =\frac{162.7 \mathrm{MPa}}{200 \mathrm{GPa}} \\
\varepsilon & =0.0008135
\end{aligned}
$$

\section{b. Voltage Difference Limit}

If the machine is loaded, the strain that occurs at the critical location is transmitted to the strain gauge and then to the strain module. However, the strain module is not read the strain but the output voltage of the Wheatstone bridge. So the strain that occurs needs to be converted to voltage first. Conversion of strain into voltage using Equation 3 [11]. The input voltage $\left(E_{i}\right)$ used is 5 volts and the strain gauge used is 350 ohms with $G F$ 2 .

$$
\begin{aligned}
\frac{\Delta E_{o}}{E_{i}} & =\frac{G F \varepsilon}{4} \\
\Delta E_{o} & =\frac{G F \varepsilon E_{i}}{4} \\
\Delta E_{o} & =\frac{(2)(0.0008135)(5 \text { Volt })}{4} \\
\Delta E_{o} & =0.00203375 \text { Volt }
\end{aligned}
$$

The value of this voltage difference is very small so it needs to be enlarged so that it can be read by Arduino. Therefore, a gain $(G)$ of 235 is used which is available on the strain module by turning the potentiometer for its adjustment.

$$
\begin{aligned}
& \Delta E_{o, \text { gain }}=(0,00203375 \text { Volt })(235) \\
& \Delta E_{o, \text { gain }}=0.47793125 \text { Volt }
\end{aligned}
$$

c. Analog Data Difference Limit

The results of the voltage readings displayed on the Arduino serial monitor are still analog data. To convert the voltage into analog data, Equation 4 [12] is used.

$$
\begin{aligned}
E_{o} & =\frac{E_{i}}{1024} D A \\
\Delta D A_{b} & =\frac{1024 E_{o}}{E_{i}} \\
\Delta D A_{b} & =\frac{1024(0.47793125 \text { Volt })}{5 \mathrm{~V}} \\
\Delta D A_{b} & =97
\end{aligned}
$$

Therefore, the difference in analog data $(\Delta \mathrm{DA})$ displayed on the Arduino serial monitor during the experiment should not exceed and as much as possible approach 97.

\subsection{Experimental Procedure}

Experiment is carried out by giving a slowly increasing working pressure starting from 0 bars until the analog data read on the Arduino serial monitor approaches the analog data limit. Experiments are divided into two types of measurements, namely stress measurements and deflection measurements. The gauge setup is shown in Figure 8 and Figure 9.

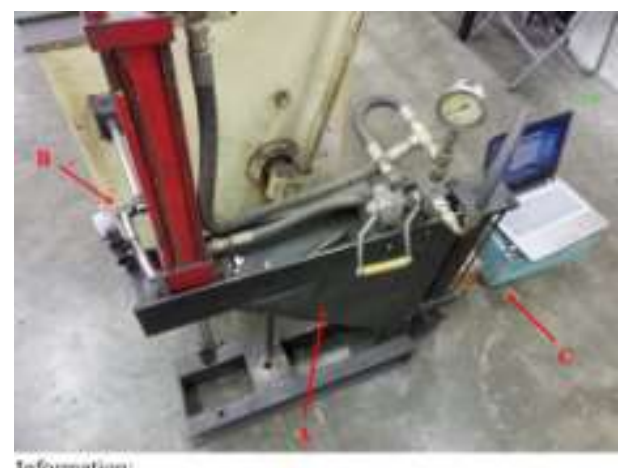

$$
\begin{aligned}
& \text { A. Plate punching and beoding combination machine } \\
& \text { B. Dial indicaror } \\
& \text { C. Voltoge measuring device }
\end{aligned}
$$

Figure 8: Experimental set-up

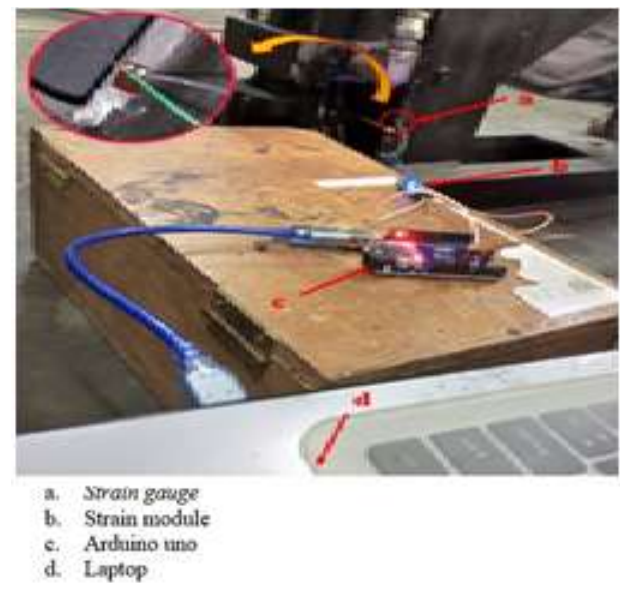

Figure 9: Stress measurement set-up

\subsection{Analysis and Discussion}

The analysis was carried out by comparing the experimental measurement results to the simulation results. In addition, an analysis of the punch force, which is transmitted from the working pressure and its utilization in the punching process, is also carried out. The force required to punching is essentially 
the product of the shear strength of the sheet metal and the total area to be cut along the edges [1]. The punch force required for punching can be determined by Equation 5 .

$$
F_{p}=0.7 t L \sigma_{t}
$$

\subsection{RESULT}

Performance analysis on this plate punching and bending combination machine was done by comparing the simulation and experimental methods. The results obtained from this research were the working pressure of the machine, the maximum punch force that can be produced and the utilization of the punch force.

\subsection{Simulation Result}

Figure 10 shows the results of the simulation analysis in the form of the maximum stress that occurs. This stress analysis uses von Mises stress where the loads given include punch force (yellow arrow) of $5100 \mathrm{~N}$, gravity due to actuator (white arrow) of $104 \mathrm{~N}$, gravity due to valve (red arrow) of $21.5 \mathrm{~N}$ and The gravity exerted by the pump is $95 \mathrm{~N}$ (green arrow) resulting in the maximum stress that occurs in the frame of this machine is $162.7 \mathrm{MPa}$ and its location is indicated by the small gray arrow around the green arrow. The maximum stress value of 162.7 MPa has not exceeded the maximum stress limit that has been determined based on a safety factor of 1.5 to the yield strength of $167 \mathrm{MPa}$, so that it can be accepted. The very influential on the magnitude of the stress that occurs is the load due to the punch force (yellow arrow), which is $5100 \mathrm{~N}$ and has the largest distance from the location of the maximum stress (critical). The greater the punch force load and the greater the distance the stress occur. The stress that occurs is the compressive stress, when viewed from the direction of loading.

Figure 11 shows the simulation results in the form of the maximum deflection that occurs, namely the y-axis deflection with a magnitude of $0.9865 \mathrm{~mm}$ and its location is indicated by a gray arrow. In Figure 11, it can be seen the location of the maximum deflection occurs at the end of the actuator frame, which is closest to the actuator gravity (white arrow). This is because at the end there of a punch force (yellow arrow) where this punch force is the largest load compared to other loads.

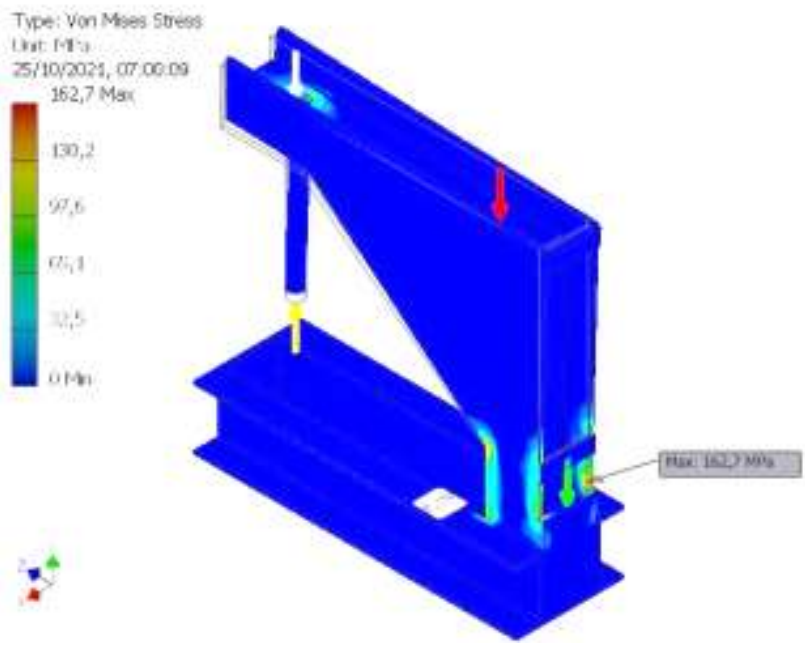

Figure 10: Simulation maximum stress
Another cause is at the location of maximum deflection. There are not other supports that can withstand the load due to the punch force. The pressure in a closed fluid can be considered uniform throughout a simple system; this equivalence is known as Pascal's law that the pressure exerted on a closed fluid will be transmitted without losses to any part of the fluid and vessel wall [13].

The input variables and output simulations that have been obtained, the work pressure applied to the simulation is unknown. The work pressure applied during the simulation can be determined using Pascal's law using Equation 6.

$$
\begin{aligned}
& p_{g}=\frac{F_{p}}{A} \\
& p_{g, s}=\frac{F_{p, s}}{A} \\
& p_{g, s}=\frac{5100 \mathrm{~N}}{1964.3 \mathrm{~mm}^{2}} \\
& p_{g, s}=2.6 \mathrm{MPa} \\
& p_{g, s}=26 \mathrm{Bar}
\end{aligned}
$$

The output obtained from the simulation is as follows:

$$
\begin{aligned}
& \sigma_{s}=162.7 \mathrm{MPa} \quad \text { (Simulation maximum stress) } \\
& \delta_{s}=0.9865 \mathrm{~mm} \quad \text { (Simulation maximum deflection) } \\
& p_{g, s}=26 \mathrm{Bar} \quad \text { (Simulation gauge pressure) }
\end{aligned}
$$

\subsection{Result of Experiment}

The entire complete data reading results are shown in Table 2. Based on Table 2, it can be determined the difference in analog data $(\triangle \mathrm{DA})$ obtained during the test, which is as follow:

$$
\begin{aligned}
& \Delta D A=D A_{2}-D A_{1} \\
& \triangle D A=268-175 \\
& \Delta D A=93
\end{aligned}
$$

The difference in analog data $(\triangle \mathrm{DA})$ obtained during the test that has been averaged is 93 . It is below the limit of the difference in analog data $\left(\Delta D A_{b}\right)$, which is 97 . However, there is still a difference of 4 analog data; this is done so that the test which was carried out did not exceed the experimental limit. Besides, there was an unstable reading of the data up to \pm 3 , which is shown in Table 2.

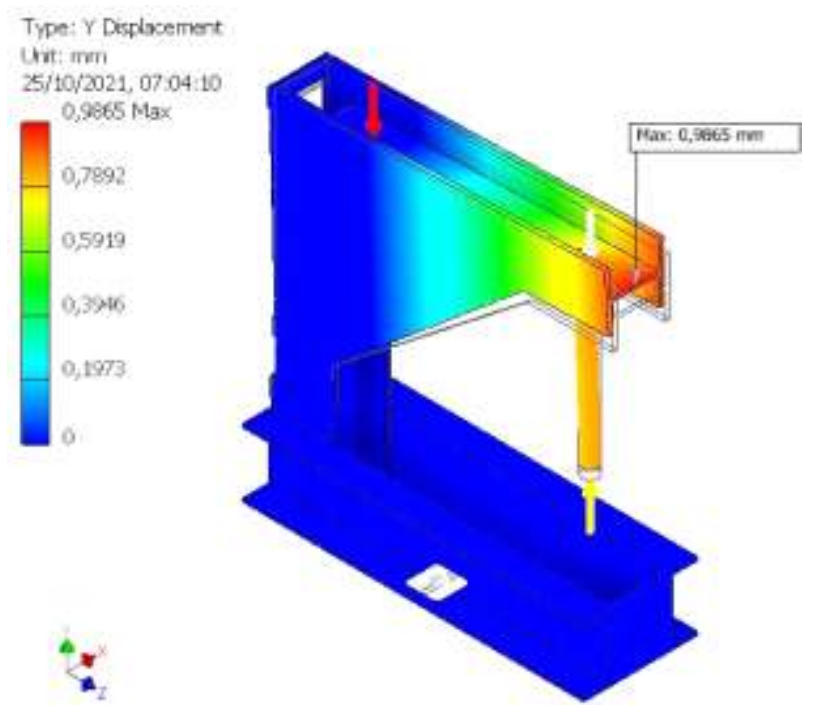

Figure 11: Simulation maximum deflection

121 JOMAse | Received: 30-August-2021| Accepted: 30-November-2021| [(65) 3: 117-124] Published by International Society of Ocean, Mechanical and Aerospace Scientists and Engineers, www.isomase.org., ISSN: 2354-7065 \& e-ISSN: 25276085 
This is also because the measurement only done once. It is feared due to the data readings carried out by the strain gauge sensor would not longer be the same, if it was repeated with the same strain gauge.

Table 2: Analog data reading

\begin{tabular}{|c|c|c|c|c|c|}
\hline $\begin{array}{c}\text { Time } \\
\text { (second) }\end{array}$ & $\begin{array}{l}\text { Analog } \\
\text { Data } \\
\text { Sensor }\end{array}$ & Information & $\begin{array}{c}\text { Time } \\
\text { (second) }\end{array}$ & $\begin{array}{c}\text { Analog } \\
\text { Data } \\
\text { Sensor }\end{array}$ & Information \\
\hline 1 & 173 & \multirow{20}{*}{$\begin{array}{c}\text { Initial condition } \\
\left(p_{R, 8}=0 \text { bar }\right) \\
D A_{1}=175\end{array}$} & 31 & 233 & \multirow{10}{*}{$\begin{array}{c}\text { Load increased } \\
\text { slowly } \\
\left(0<p_{a, e}<27,7 \text { bar }\right)\end{array}$} \\
\hline 2 & 174 & & 32 & 236 & \\
\hline 3 & 175 & & 33 & 230 & \\
\hline 4 & 172 & & 34 & 232 & \\
\hline 5 & 175 & & 35 & 232 & \\
\hline 6 & 174 & & 36 & 230 & \\
\hline 7 & 174 & & 37 & 243 & \\
\hline 8 & 175 & & 38 & 255 & \\
\hline 9 & 171 & & 39 & 260 & \\
\hline 10 & 174 & & 40 & 267 & \\
\hline 11 & 173 & & 41 & 264 & \multirow{20}{*}{$\begin{array}{c}\text { Final condition } \\
\left(p_{g, e}=27,7 \mathrm{bar}\right) \\
D A_{2}=268\end{array}$} \\
\hline 12 & 180 & & 42 & 270 & \\
\hline 13 & 176 & & 43 & 271 & \\
\hline 14 & 175 & & 44 & 270 & \\
\hline 15 & 179 & & 45 & 264 & \\
\hline 16 & 178 & & 46 & 263 & \\
\hline 17 & 174 & & 47 & 267 & \\
\hline 18 & 174 & & 48 & 265 & \\
\hline 19 & 174 & & 49 & 265 & \\
\hline 20 & 172 & & 50 & 264 & \\
\hline 21 & 177 & \multirow{10}{*}{$\begin{array}{c}\text { Load increased } \\
\text { slowly } \\
\left(0<p_{g, 8}<27,7 \text { bar }\right)\end{array}$} & 51 & 266 & \\
\hline 22 & 178 & & 52 & 263 & \\
\hline 23 & 183 & & 53 & 270 & \\
\hline 24 & 187 & & 54 & 270 & \\
\hline 25 & 197 & & 55 & 271 & \\
\hline 26 & 197 & & 56 & 270 & \\
\hline 27 & 199 & & 57 & 271 & \\
\hline 28 & 210 & & 58 & 271 & \\
\hline 29 & 213 & & 59 & 270 & \\
\hline 30 & 227 & & 60 & 269 & \\
\hline
\end{tabular}

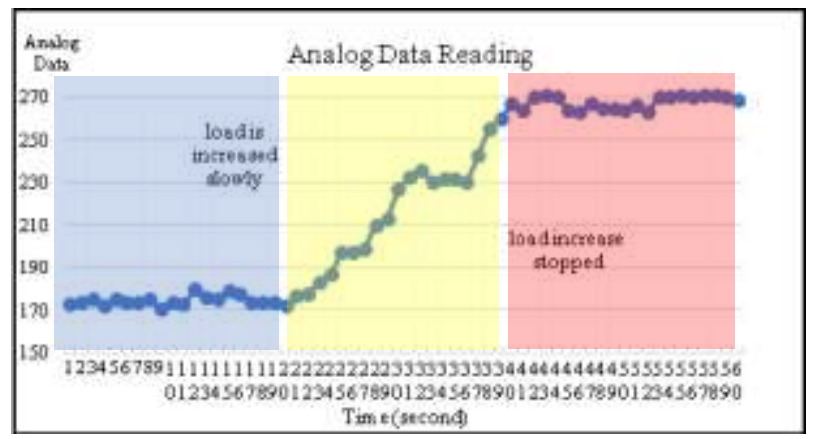

Figure 12: Analog data reading chart

Figure 12 shows the reading of analog data that occurred during testing. Initially the machine is in a condition without load indicated at the time of reading time of 1 second to 20 seconds, then obtained the average analog data reading of 175 . Furthermore, the load began to be increased slowly at a time reading of 21 seconds to 40 seconds, and then the increase in load resulted in the reading of analog data changed from 175 to 267. Furthermore, the load increase was stopped during the reading time of 41 seconds and held until the reading time of 60 seconds, and then the average analog data reading of 268 was obtained.

When the load is applied and then held and the analog data difference $(\triangle \mathrm{DA})$ is reached at the 41 second to 60 second reading time interval shown in Figure 12. The pressure gauge and dial indicator readings are also recorded. The reading from the pressure gauge, the analog data difference is reached to 27.7 bars, as shown in Figure 13. The deflection reading from the dial indicator, the analog data difference was reaching of 1.15 $\mathrm{mm}$. The dial indicator readings are shown in Figure 14.

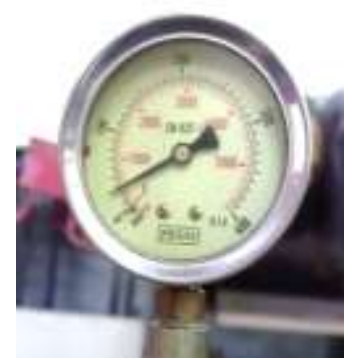

Figure 13: Pressure gauge value when analog data difference is reached

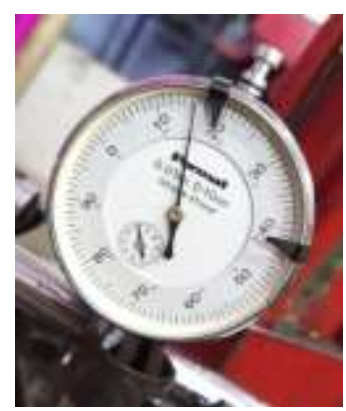

Figure 14: Dial indicator value when analog data difference is reached

The results obtained from the experiments that have been conducted are as follows:

$$
\begin{array}{lll}
\sigma_{e}=154.6 \mathrm{MPa} & & \text { (Maximum experiment stress) } \\
\delta_{e}=1.15 \mathrm{~mm} & & \text { (Maximum experiment deflection) } \\
P_{g, e}=27.7 \mathrm{Bar} & & \text { (Pressure gauge experiment) }
\end{array}
$$

\subsection{Comparison of Simulation and Experiment Results}

The results of the simulation and experimental tests were compared with the purpose of validating the experimental data. The overall data from the simulation and experimental results are presented in Table 3. The difference between the two is expressed in percent error.

In Table 3, it can be seen that there is a difference between the results of the simulation and the experiment. The error obtained in the voltage result has not reached 5\%. Things that can cause this error include noise factors in the measuring instrument of the strain module where in the strain module there are many electrical resistances, capacitors and other electrical components. In addition, the use of cables to connect strain gauges, strain modules, arduino and laptops can also affect the reading results. In addition, accuracy and slope when attaching strain gauges at critical locations are also very influential because strain gauges are very sensitive.

Table 3: Comparison of simulation and experiment results

\begin{tabular}{lccc}
\hline Result & $\begin{array}{c}\text { Stress } \\
\text { (MPa) }\end{array}$ & $\begin{array}{c}\text { Deflection } \\
\text { (mm) }\end{array}$ & $\begin{array}{c}\text { Werking Pressure } \\
\text { (bar) }\end{array}$ \\
\hline Simulation & 162.7 & 0.9865 & 26 \\
Experiment & 154.6 & 1.15 & 27.7 \\
Error $(\%)$ & 4.98 & 16.57 & 6.54 \\
\hline
\end{tabular}


In the results of deflection error obtained exceeded $15 \%$ where the simulation measurement obtained by $0.9865 \mathrm{~mm}$ and had a difference of $0.1635 \mathrm{~mm}$ with an experimental result of $1.15 \mathrm{~mm}$. This difference can be caused by the installation of an indicator dial measuring device that is not perpendicular to the surface of the measured location, so that the slightest angle can affect the results of the experimental readings.

The simulation work pressure $\left(p_{g, s}\right)$ is obtained 26 bars and the experimental working pressure $\left(p_{g, e}\right)$ is obtained 27.7 bars. The error obtained from these two methods is $6.54 \%$. This working pressure is still very far from the working pressure provided by the hydraulic pump, which is 700 bars. Therefore, it is necessary to make changes and additions to the construction of the engine frame, so that the working pressure can be increased again in order to approach the availability of the working pressure of the hydraulic pump. Then, the hydraulic pump can be utilized more optimally.

\subsection{Maximum Punch Force}

The working pressure obtained from the simulation method $\left(P_{g, S}\right)$ is 26 bars and the experimental working pressure $\left(P_{g, e}\right)$ is 27.7 bars. From these two results, the experimental working pressure, which is 27.7 bars, is used because this is the actual result of the working pressure obtained when a real load is applied to the machine.

The pressure in a closed fluid can be considered uniform throughout a simple system, this equality is known as Pascal's law, and namely the pressure exerted on a closed fluid would be transmitted without reducing to every part of the fluid and the walls of the vessel [11]. To find out the maximum punch force $\left(F_{p, \text { maks }}\right)$ that can be produced from a working pressure of 27.7 bar, Pascal's law is used because this machine uses a hydraulic system as the driving force.

$$
\begin{aligned}
& P_{g}=\frac{F_{p}}{A} \\
& F_{p, e}=P_{g, e} A \\
& F_{p, e}=(27.7 \mathrm{Bar})\left(1964.3 \mathrm{~mm}^{2}\right) \\
& F_{p, e}=(2.77 \mathrm{MPa})\left(1964.3 \mathrm{~mm}^{2}\right) \\
& F_{p, e}=5441 \mathrm{~N}
\end{aligned}
$$

The working pressure used is the experimental working pressure; therefore the experimental punch force $\left(F_{p, e}\right)$ is the machine's maximum punch force $\left(F_{p, \text { maks }}\right)$.

$$
\begin{gathered}
F_{p, \text { maks }}=F_{p, e} \\
F_{p, \text { maks }}=5441 \mathrm{~N}
\end{gathered}
$$

The punch force required to carry out the punching process can be determined using Equation 6. The results of the calculation of the variable limit in the punching are shown in graphical form in Figure 15. Figure 15 shows the utilization of the maximum punch force to determine the thickness limit of the work piece in the circular punching process of pure aluminum, brass and copper work pieces with varying diameters. In general, from the three types of work pieces, it can be concluded that the relationship between thickness and diameter of the work piece is inversely proportional. With a constant working pressure of 27.7 bars, the greater the thickness of the work piece, the smaller the diameter that can be worked on the work piece and vice versa.

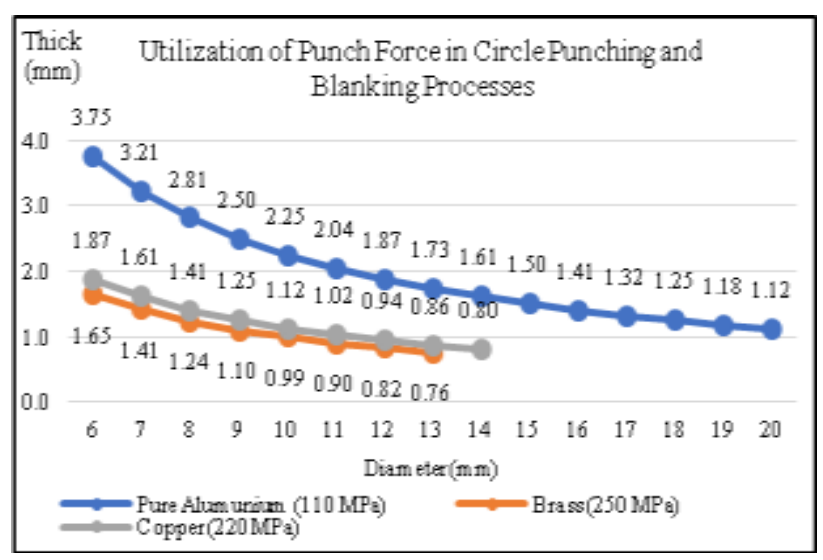

Figure 15: Utilization of punch force in the punching and blanking process

The product of the thickness and the diameter affects the size of the shear area to be cut, if the shear area is larger, the larger the punch force is needed, as a result, the working pressure required will also be greater.

In Figure 15, there are three types of work piece materials that have different tensile stresses, in pure aluminum $110 \mathrm{MPa}$, copper $220 \mathrm{MPa}$ and brass $250 \mathrm{MPa}$. For example, in the process of punching with a diameter of $6 \mathrm{~mm}$, the thickness of the work piece that can be cut on pure aluminum material is $3.75 \mathrm{~mm}$, while copper is only able to cut on a work piece thickness of $1.87 \mathrm{~mm}$ and brass is only able to cut on a work piece thickness of $1.65 \mathrm{~mm}$. In another example of the punching process with a diameter of $13 \mathrm{~mm}$, the work piece thickness that can be cut on pure aluminum material is 1.73 $\mathrm{mm}$, while copper is only able to cut with $0.86 \mathrm{~mm}$ thick work pieces and brass is only able to cut with $0.76 \mathrm{~mm}$. From these two examples it can be concluded that with the same diameter, giving the punch force and working pressure, the greater the value of the tensile stress of the work-piece material, the smaller the thickness of the work-piece that can be punched and vice versa. Therefore, when using this punching and bending combination machine in the punching process, it is necessary to pay attention to the limits set in Figure 15

\subsection{CONCLUSION}

Based on the results of the analysis that has been carried out, it can be concluded that the work pressure that can be held by a plate punching and bending combination machine is 27.7 bars. This 27.7 bars pressure is obtained by applying safety factors based on the yield strength of the frame material, which is 1.5 .

The punch force required in the punching process (punching and blanking) depends on the input variable that is tensile strength material, thick and around the hole. The larger the input variable, the greater the punch force needed for a hole. The punch force that can result from maximum working pressure is $5441 \mathrm{~N}$.

\section{ACKNOWLEDGEMENTS}

The authors would like to convey a great appreciation to lecturers and friends in Technology Production Mechanical 
Engineering Department, Universitas Riau, Indonesia for supporting this research.

\section{REFERENCES}

[1] Kalpakjian, S. \& S.R Schmid. 2010. Manufacturing Engineering and Technology. Edition 6. Pearson Prentice Hall. Upper Saddle River-New Jersey.

[2] Rizza, M.A. (2014). Analisis proses blanking dengan simple press tool. Jurnal Rekayasa Mesin. 5(1): 85-90.

[3] Yunus, N. dan Harianto, J. 2015. Perancangan dan Pembuatan Mesin Kombinasi Pelubang dan Penekuk Pelat. Tugas Akhir, Fakultas Teknik, Universitas Riau, Pekanbaru.

[4] Lubis, F.R. dan Yohanes (2018). Analisis pengaruh bentuk mata tool punch terhadap gaya dan kualitas pemotongan pada proses blanking. Jurnal Online Mahasiswa (JOM) Bidang Teknik dan Sains, 5(2).

[5] Safruddin, R.A., Huda, F. \& Utomo, S. (2018). Analisis pengukuran tegangan pada struktur pelat berbasis microcontroller arduino. Jurnal Online Mahasiswa (JOM) Bidang Teknik dan Sains, 5(2).

[6] Yohanes, Y., \& Andri, N. (2020). Performance of dynamometer with sensor type single bar for measuring drive power of rotary friction welding machine, Journal of Ocean, Mechanical and Aerospace -Science and Engineering-, 64(3), 73-80.
[7] Yohanes, Y., \& Alqolbi, M. (2020). Development of dynamometer based on strain gauge with sensor rod type four square stalk to measuring the drive power of rotary friction welding machine, Journal of Ocean, Mechanical and Aerospace -Science And Engineering-, 64(1), 9-15.

[8] Wibawa, L.A.N. (2019). Pengaruh pemilihan material terhadap kekuatan rangka main landing gear untuk pesawat UAV. Jurnal Teknologi dan Terapan Bisnis (JTTB), 2(1), 48-52.

[9] Hearn, E.J. (1997). An Introduction to the Mechanics of Elastic and Plastic Deformation of Solids and Structural Materials. Edition 3, Scotprint, Musselburgh.

[10] Norton, R.L. (2011). Machine Design An Integrated Approach. Edition 4, Pearson Prentice Hall, Upper Saddle River-New Jersey.

[11] Figliola, R.. \& Beasley, D.E. (2011). Theory and Design for Mechanical Measurements. Edition 6, John Wiley, Hoboken-New Jersey.

[12] Budiarto, M.A. (2019). Simulator Kendali Kursi Roda Menggunakan Sensor Flex Wireless Berbasis Mikrokontroler. Proyek Akhir, Fakultas Teknik Universitas Yogyakarta, Yogyakarta.

[13] Halliday, D.R., Resnick \& Walker, J. (2014) Fundamental of Physics. Edition 10, Wiley and Sons, New York. 